Article

\title{
Community Supported Agriculture as a Driver of Food-Related Well-Being
}

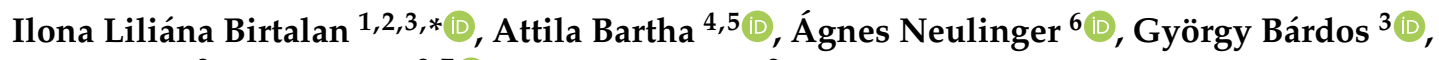 \\ Attila Oláh ${ }^{2}$, József Rácz ${ }^{2,7}$ and Adrien Rigó ${ }^{2}$ \\ 1 Doctoral School of Psychology, ELTE Eötvös Loránd University, 1075 Budapest, Hungary \\ 2 Institute of Psychology, ELTE Eötvös Loránd University, 1064 Budapest, Hungary; \\ olah.attila@ppk.elte.hu (A.O.); racz.jozsef@ppk.elte.hu (J.R.); rigo.adrien@ppk.elte.hu (A.R.) \\ 3 Institute of Health Promotion and Sport Sciences, ELTE Eötvös Loránd University, 1117 Budapest, Hungary; \\ bardos.gyorgy@ppk.elte.hu \\ 4 Centre for Social Sciences, Hungarian Academy of Sciences Centre of Excellence, 1097 Budapest, Hungary; \\ attila.bartha@uni-corvinus.hu \\ 5 Institute of Economic and Public Policy, Corvinus University of Budapest, 1093 Budapest, Hungary \\ 6 Institute of Marketing, Corvinus University of Budapest, 1093 Budapest, Hungary; \\ agnes.neulinger@uni-corvinus.hu \\ 7 Faculty of Health Sciences, Semmelweis University, 1088 Budapest, Hungary \\ * Correspondence: birtalan.liliana@ppk.elte.hu
}

Received: 6 May 2020; Accepted: 31 May 2020; Published: 2 June 2020

\begin{abstract}
Background: There is a growing amount of research interest to understand the role of food in well-being. The demand for community supported agriculture (CSA), bringing people spatially, economically, and socially closer to food, is continuously expanding. CSAs play an important role in both sustainable agriculture practices and influencing consumers' food-related practices, but yet have received little attention in well-being research. Methods: This study explores food-related well-being among CSA members by using an exploratory, qualitative research design and a thematic analysis of semi-structured interviews. Results: The findings stress the relevance of psychological, social, and spiritual aspects of food-related well-being beyond the nutritional characteristics of food in CSA. Conclusion: The role of sustainable agriculture in contributing to food-related well-being becomes particularly evident based on consumers' experiences. These results are important in convincing people that their food-related experiences belong to their perceived well-being as well as stimulating people to elevate their multidimensional expectations in relation to food.
\end{abstract}

Keywords: community supported agriculture; food-related well-being; bio-psycho-socio-spiritual model; sustainability; local food; explorative research; qualitative study

\section{Introduction}

The desire to look and feel one's best is almost universal and most people recognize that what they eat plays an important role in optimal health. At the same time, there has been a shift in agricultural policies from large agri-food systems towards local and sustainable food systems in the name of sustainability and public health [1]. Similarly, consumers seem to be increasingly aware of the sustainability of food production, preferring to eat food which respects these principles [2].

Throughout history food has always been an essential part of living, and in line with this an accumulating body of research suggests that food can contribute to multiple functions in life, such as enjoying the moment, appreciation of authenticity, or engaging in pro-environmental behavior [3-5]. Indeed, food is a specific aspect of well-being that affects the subjective evaluation of how people 
perceive their life [6,7]. In understanding the complex role of food on well-being, Block et al. [8] (p. 5) suggest a shift towards a broader, "more positive, holistic" approach.

Studies suggest that the influence of food on well-being is embedded in the sensual, cultural, and ecological context of food production and supply [9-11]. Alternative food networks (AFNs), including community-supported agriculture initiatives (CSAs), box schemes, farmers' markets, and urban community gardens offer alternative food sources for consumers providing local embeddedness and a connection to nature [12-14]. Although sustainable production to mainstream food manufacturers and retailers continues to expand, the effect of their food products on subjective well-being is still questionable. Som Castellano [15] (p. 448) mentioned several aspects of subjective well-being related to AFNs' practices; namely well-being "inside and outside the home", environmental well-being, and community well-being, whilst also acknowledging the consequences of the membership on one's perceived quality of life. Other scholars, such as Neulinger et al. [16] found a high level of life satisfaction among members of different AFNs, particularly in the case of experienced members with high engagement and a strong commitment to alternative food consumption.

CSA constitutes an important AFN strategy with the potential to contribute to greater food system sustainability. It is a risk-sharing form of AFN and, in its base form, a small-scale farm provides week-to-week freshly harvested, organic vegetables to CSA members for a specified period of time $[17,18]$. CSAs provide a higher intake of vegetables of local origin whilst also emphasizing the social and environmental aspects of farming [19]. Many CSAs aim to enhance the ecological sustainability of the agri-food system through social inclusion of production and consumption [20]. Not surprisingly, CSAs contribute to a modified production-consumption practice [21]. Consumption in CSAs is unique in several aspects: Namely the origin of food, the trust in food quality, the sense of community and the relationship network, all being highly important for consumers in these alternative systems [22].

An accumulating body of research suggests that CSA has a significant impact on health [18,23-25], but very little is understood about how it affects the food-related well-being experiences of CSA participants. This research used an exploratory, qualitative research design and has tried to bridge the gap between the understanding of food-related well-being and CSA research.

\section{From the Research Area of Health Psychology to Food-Related Well-Being in CSA}

Well-being and health are key goals for sustainable development in order to achieve a high quality of life for all [26]. Engel's bio-psychosocial model [27], in line with the original definition of health by the WHO [28]: "a state of complete physical, mental and social well-being and not merely the absence of disease or infirmity", pointed out that health, as optimal functioning, is the result of interactions under a unifying framework. This model has been broadened to include a spiritual/existential dimension in recent years to become a bio-psycho-socio-spiritual model (BPSS) [29]. This already includes the thoughts or experiences of wider patterns of social influence that can be considered as an ally in healthy behavior [30,31].

\subsection{The Bio-Psycho-Socio-Spiritual Model of Health Psychology}

The BPSS model reflects a multiparadigmatic view and addresses all health related factors contributing to the level of subjective well-being [32]. This integrated framework between health and well-being better explains the complexity of personal experiences [33]. It forces a focus on all system levels, including individual, close relational (e.g., family-relational), or community levels; recognizing the interrelatedness of these different levels of conditions [34].

In BPSS, the four domains of health are physical (i.e., body functioning), psychological (i.e., personal growth), social (i.e., interpersonal relations), and spiritual (i.e., finding meaning and one's place within the universe), which are the fundamental building-blocks of perceived well-being [29,32]. All domains represent a primary source and have the potential strength to influence the perceived health and well-being of individuals, and to understand their ability to adapt to and self-manage challenges [35,36]. 
However, according to its relational approach, each well-being aspect can interfere with and influence other aspects [37]. This integrated model of health and well-being provides various domains of interventions in practice and can be used to understand people's actions and decisions on a daily basis. This research draws upon the BPSS approach as a foundational theoretical perspective.

\subsection{Food-Related Well-Being}

Taking greater account of the complexity of food and its intricate relations to well-being, much of the work tends to illustrate the potential of food for being bound to health in a variety of ways [38]. In recent years, a specific concept of well-being, food-related well-being, has generated an abundance of literature. In this way, food-related well-being explicitly incorporates subjective aspects of well-being, and thus also physical, psychological, or socio-environmental aspects $[8,9,39]$. In this section, we present these aspects by outlining their relationship to the well-being dimensions of BPSS (main findings are summarized in Table 1).

Table 1. Results of food-related well-being studies.

\begin{tabular}{cr}
\hline Well-Being Dimensions & Results of Food-Related Well-Being Studies \\
\hline Physical & $\begin{array}{r}\text { Fruit and vegetable consumption: Reducing life-threatening diseases such as } \\
\text { cancer or cardiovascular disorders, higher energy levels } \\
\text { Organic food: Better sensory experiences }\end{array}$ \\
\hline Psychological & $\begin{array}{c}\text { Higher intake of fruits and vegetables: Lower odds of depression, improving } \\
\text { life satisfaction, more positive emotions, more curiosity and creativity } \\
\text { Healthy eating: Closer to immediate improvements of well-being }\end{array}$ \\
\hline Social & $\begin{array}{c}\text { Sharing food: Stronger sense of solidarity } \\
\text { Local origin of food: Stronger sense of community belonging }\end{array}$ \\
\hline Spiritual & $\begin{array}{c}\text { Organic food: Spiritual sensitivity } \\
\text { Food with eco-labels, ethical marketplaces: Experience of an integral connection } \\
\text { to the environment }\end{array}$ \\
\hline
\end{tabular}

\subsubsection{Food-Related Physical Well-Being}

Food and its effect on bodily functions is inextricably linked to physical well-being. The Dietary Guidelines for Americans [40] promote the daily consumption of a wide variety of fruit and vegetables as they are packed with vitamins, minerals, antioxidants, and fiber. In line with this, based on fruit and vegetable intake, a large number of studies have taken up the connection between CSA and physical health $[24,25,41-43]$. Fruit and vegetable consumption helps to reduce the risk of physical health problems including life-threatening diseases such as cancer, cardiovascular disorders, and diabetes $[44,45]$. Food consumption also influences sleeping patterns, energy levels, and general health $[46,47]$. An increasing number of studies confirm the possible role of diet and different food-elements in health-related epigenetic processes [48]. Studies investigating the impacts of consuming non-chemical natural food reveal another aspect of physical pleasure: Better sensory experiences such as taste or smell $[49,50]$.

\subsubsection{Food-Related Psychological Well-Being}

Numerous studies have confirmed that food can influence our emotions and attitude alongside our psychological well-being. The consumption of fruits and vegetables is accompanied by an increase in positive mental state: They are associated with higher levels of positive emotions or improved mood, happiness, mental health, and attitude [51-53]. Moreover, Blanchflower et al. [54] suggest that a higher intake may help improve personal life satisfaction. Exploring the relationship between what people eat and how they feel, fruit and vegetable consumption is associated with more intense feelings of 
curiosity and creativity [55]. Furthermore, increased consumption of fruits and vegetables is associated with reduced odds of depression and of suffering from distress [56,57]. Interestingly, on the basis of an Australian healthy-eating campaign, Mujcic et al. [58] suggest that the positive effects of healthy eating on the quality of life (happiness, life satisfaction, and well-being) actually grow at a faster rate than the demonstrable beneficial effects on physical health.

\subsubsection{Food-Related Social Well-Being}

The positive impact of food consumption on well-being is not limited to what people consume but extends to a broader social environment of food intake $[4,11,59,60]$. The social environment can influence eating patterns or food choices $[1,61,62]$. Moreover, food can be a tool for strengthening relationships with others; sharing food brings people together and nurtures a sense of solidarity. How people choose a meal in a family offers an opportunity for caring about other's needs, social responsibilities, or social behavior [63,64].

Interestingly, consuming local food affects social well-being; local products contribute to social cohesion and maintain family-like social ties [19,65]. Buying local food provides space for a sense of community by fostering interaction with producers or other like-minded consumers [66]. Echoing other studies' concerns there are links between social well-being and organic products [67].

\subsubsection{Food-Related Spiritual Well-Being}

Spirituality has received many definitions in health research, and one of the most comprehensive is from Puchalski [68] (p. 646) who proposed a definition as "Spirituality is a dynamic and intrinsic aspect of humanity through which persons seek ultimate meaning, purpose, and transcendence, and experience relationship to self, family, others, community, society, nature, and the significant or sacred." The implications of this definition strongly suggest that spirituality in relation to food is about how a person integrates these relationships into a perspective.

Less is known about the aspects of spiritual dimensions of well-being in relation to food in practice. Although spirituality is routinely part of psychological investigations in food-related well-being studies [69-71], spiritual aspects are not salient in this area [8,11,72]. Some studies concentrating on organic food explore whether organic food purchasing is related to a spiritual lifestyle [73,74]. Other research suggests that eco-labels and ethical marketplaces (fair trade, organic etc.) seek to rate values (e.g., sustainability, human responsibility) by addressing the consumer's spiritual attributes as well [75]. The alternative ways of how food is acquired and resituated re-embeds people to nature and serves to uphold an integral connection to the environment [76]. The close proximity and accountability of the producers of goods attract consumers with ecological concerns or moral imperatives which may reflect social issues, but may also imply a deeper connection to human nature [77,78].

Although spirituality is often described in terms of religious beliefs and practices, BPSS handle spirituality as a distinct, albeit related construct to religion, which focuses on the essence of a human being contributing to one's overall quality of life $[37,79,80]$. In practice, food helps to establish rituals and enable practices through which people render meaning and influence the way in which people relate to food consumption as an aspect of life [81].

\subsection{Community Supported Agriculture in Hungary}

Hungary offers an interesting context for a food-related well-being research. For an Eastern European country, it shows relatively high rates of food self-provisioning [82]. In a regional context, this has an impact on leisure activities (food provisioning as a hobby), and in addition, it serves as a way to access healthy food [83]. As CSAs reconnect consumers with producers and offer insight into production methods, consumers more easily become engaged in consuming both more healthfully and in a more environmentally friendly way, providing a sense of community [82]. Hungary is recognized as a country with a low level of social connections, civic engagement, environmental quality and low 
in subjective well-being [84], and thus CSAs may facilitate more well-being practices through building communities linked to healthy food.

Little information is available on the situation of CSAs regarding Eastern European countries where CSA is a relative new phenomenon. Regarding the Hungarian setting, although farmers' markets and farm gate sales already play a significant role in the country, CSAs offer a new, noteworthy market alternative, reconnecting consumers with producers [82]. CSAs build an open space for active and direct producer-consumer cooperation, and thus, offer a new model for the Hungarian food system: It is based upon the idea of being closely related to food in spatial, economic, and social terms; thus enhancing value-laden and trust-based food quality attributes in relation to local farming [85].

The first three Hungarian CSAs began in 2011, starting as a grassroots movement based on a partnership and solidarity between consumers and organic food producers. There are currently sixteen existing vegetable CSAs alongside box schemes or solidarity purchasing groups [86]. All CSAs in Hungary are small-scale farms and vary respectively in their capacity, number of pick-up points, and monthly price. The farmer provides mostly organic products in different box sizes, and members can select the size in order to meet household vegetable demand. In their study, Samoggia [22] compared Hungarian and American farmers and found that Hungarian farmers in particular emphasize CSA's positive ability to produce healthy food. These farmers are strongly committed to provide local produce to the community while at the same time maintaining soil quality [22].

In the typical form of a Hungarian CSA, members pay prior to the receipt of goods and, in general, receive harvested vegetables weekly over a whole year on dedicated food distribution days. All of them operate as organic farming or horticulture where members have the possibility to take part in regular farm visits, farm events, etc. The majority have between 12-100 members who are primarily conscious, urban consumers with high levels of education, and, in most cases, having a family [14,82]. Exploring the Hungarian CSA environment is a new and exciting frontier to understand in which ways sustainable agricultural practices can bring benefits.

\section{Materials and Methods}

\subsection{Aim of the Study}

Therefore, the principal research question addressed in this article is to understand food-related well-being linked to CSA membership. Due to the fact that little was known about this area, this study used a qualitative approach to explore the experiences of the CSA participants, their personal stories and perspectives, feelings and beliefs about food and food-related experiences (packing, cooking, consuming, etc.). This study is based on the interpretivist research paradigm and follows its assumptions and guidelines [87]. This design has allowed for an exploration of the complexity of the food-related well-being experiences induced by participation in CSAs.

\subsection{Study Participants and Data Collection}

The data was collected by semi-structured interviews with the members of the particular CSAs. This study used purposeful sampling in order to identify information-rich cases and to find knowledgeable and experienced interviewees. From the numerous purposeful sampling designs we wanted to describe the selected group (CSAs) in depth; therefore, we decided to use homogeneous cases for the purpose of reducing variation [88]. Researchers contacted two of the first CSAs in Hungary starting in 2011 (one from the region of the capital, one from a rural metropolis area), as well as, a third CSA (operating in a rural area with pick-up points in the capital region) in order to obtain further data. Interviewees were found through farmer referrals, CSA mail-lists, or via snowball techniques eventually leading to five of the existing sixteen CSA communities. Sampling was consistent with the aim of the study and during data collection we focused on data saturation. The members engaged in CSA participation were interviewed because of their pivotal role as key informants. 
Most of the interviewees were female (thirty-one women, four men), with the majority holding a college degree or higher (thirty-two higher, three secondary education), aged twenty-eight to sixty-two, and were financially secure. Thirty-one participants were from households comprised of couples, and four were single. Sample characteristics are in line with other research data since the average CSA member is described as mainly female, middle-aged, married, well-educated, and with above-average income [23]. The length of CSA membership varied amongst interviewees: Six were first year, and twenty-nine had been a CSA member for at least two years. They communicated various levels of integration into their CSA: 25 of them reported to be less involved in community building (only following CSA e-mails), and ten have time to engage in community building (being members of a core group).

The interviews were carried out face-to-face, lasting from an hour to two and a half hours and were conducted by the same interviewers. The semi-structured interview was conducted using a thematic guide and in a conversational, informal tone. Topics concentrated on participants' experiences in relation to healthy food consumption, knowledge, attitude and practices in CSA, meaning and significance of participation, contribution of others regarding CSA, and the future of this food-based community organization. Most of the interviews took place in the interviewee's home.

All interviews were digitally recorded and were transcribed verbatim. The first author conducted all interviews; she was responsible for addressing all topic questions and for clarifying any unclear statements of interviewees. The Research Ethics Committee evaluated ethical aspects of research activity carried out at the Institution where the study was conducted and issued ethical research permission (ELTE PPK KEB 2017/128). All subjects gave their informed consent for inclusion before participating in the study.

\subsection{Analysis}

As a qualitative analytic data tool, thematic analysis was used in order to describe the phenomenon and focusing patterns associated with the research question. This type of analysis is a commonly used qualitative method in psychology and is generally implemented when current theory or research literature on a phenomenon is limited [89]. Theoretical thematic analysis was used as researchers have attempted primarily to apply analytic interest to food-related well-being. This analysis followed the stages of thematic analysis proposed by Braun and Clarke [89].

In this analysis method, each individual piece of data (interviews) collected together makes up the data set. The entire data set has been analyzed by an iterative process and numerous deep readings through the texts. In the first phase of structuring the material this study used the Atlas.ti software. Relevant transcript passages were initially coded with words (e.g., respect, understanding, reliability, health) or phrases (e.g., having a persistent effort, staying within the comfort zone, handling vegetables) focusing on the food-related well-being features of data. Researchers made comments and notes concerning the data during this process. Codes had not been defined beforehand and were developed during the transcription readings.

After analyzing the content of the entire data set, a preliminary list of themes and patterns was identified from the initial codes (e.g., growth, devotional practice, social coherence). This preliminary list of themes was followed by a meaning interpretation and refined in consultations with the research project team expecting to distinguish structures, associations, and generic relationships between implications that are not expressly conveyed. Finally, themes were compared and organized into different emerging themes concerning BPSS.

The thematic map is the outcome of this refinement process reflecting the meanings evident throughout the entire dataset. The overall description in the results section is produced with selected quotations to capture the essence of the point this study demonstrates.

\section{Results}

The topic of CSA participation was addressed as a larger conversation to uncover the themes of well-being as to why people can accept CSA's strict commitments (e.g., farmer's risk, logistics 
challenges). Over the course of the interviews several themes emerged concerning food-related well-being in a CSA. The quotations used to support the results in this paper were chosen from amongst those that provided the best illustration of certain emerging well-being themes. The themes are summarized below: Figure 1 introduces BPSS and indicates that among aspects of food-related well-being there are both continuing and recurrent relations.
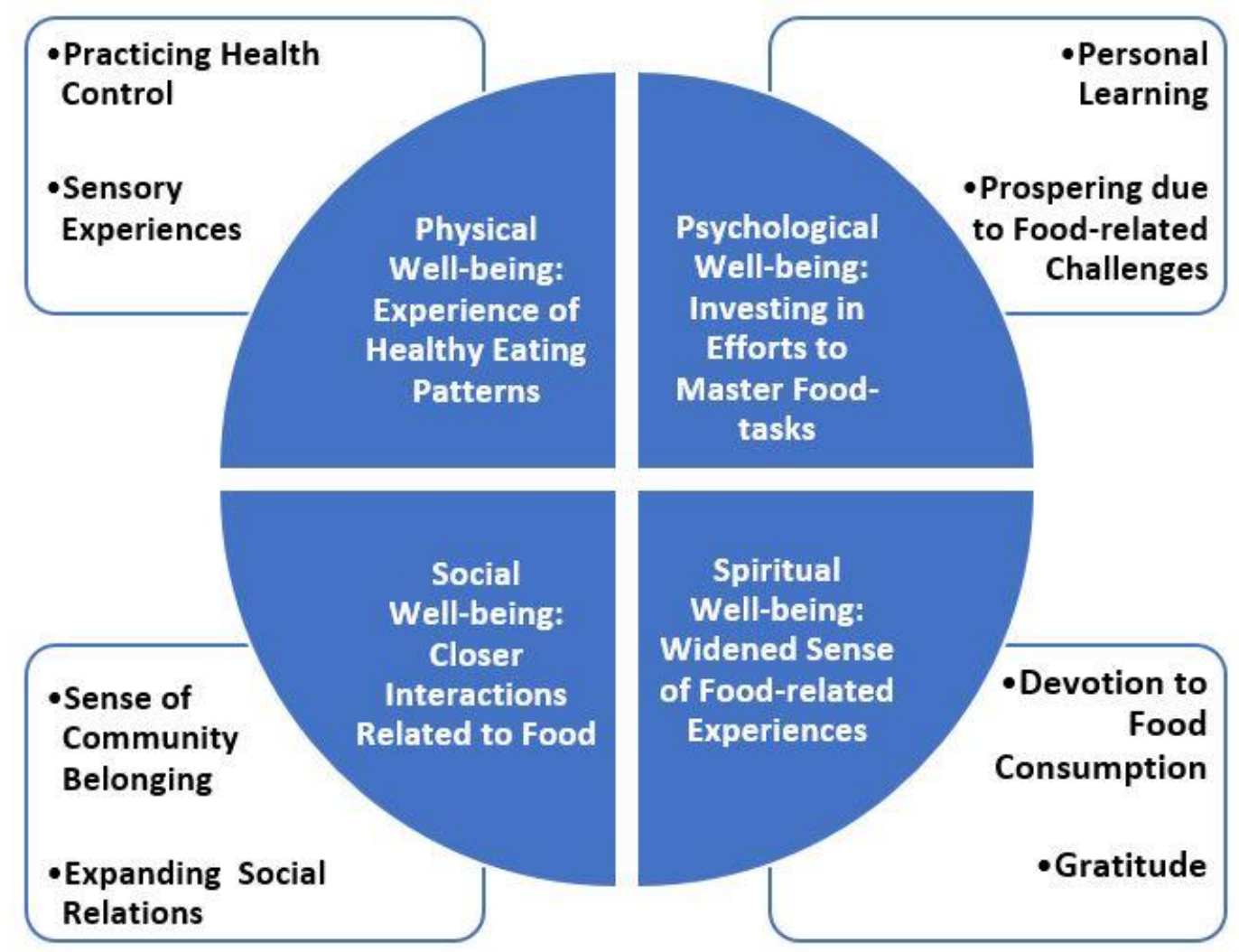

Figure 1. Emerging themes of food-related well-being in community supported agriculture (CSA).

\subsection{Physical Well-Being: The Experience of Healthy Eating Patterns}

Interviewees often described practices to illustrate their health focus or how the nature of the food received in CSA ensured physical well-being. Increased vegetable and unprocessed food consumption were associated with healthy eating patterns by the interviewees. Since the CSA produce is freshly harvested and provides a greater variety determined by seasonality, it has enhanced members' perceived food-experiences from a sensory point of view (including the experiences with earlier unknown vegetables).

\subsubsection{Practicing Health Control}

Interviewees experienced a feeling of being engaged in healthy behavior and highlighted the central role of CSA food in their health. They also mentioned regular vegetable consumption contributing to their health: "this kind of positive compulsion that I should eat vegetables is a healthier lifestyle" (Interview 22). In their view the most substantial health-related changes involved exposure to vegetables in larger quantities: "Since we started she eats a lot more vegetables" (Interview 7), or eating more non-processed food: "We eat greens at least once a day, raw, and we like it (Interview 9). Farming techniques (e.g., organic methods) were often mentioned as an important element of perceived personal health control: "She can do it in an organic way so that she does not use synthetic fertilizers or pesticides and thus does no wrong to the product" (Interview 1). Over a long period, consumed organic food was portrayed as being life enhancing or as offering a healthier regimen: "It is sure that CSA helped to make me more conscious of what 
we eat, what we drink, what we cook, and how we eat regularly" (Interview 19). Of particular interest was the discussion with parents who practice health control over their babies via feeding them with CSA vegetables: "The consciousness that we eat normally and my baby is getting good food [natural pesticides and fertilizers, organic cultivation, biological diversity]_I know that this is more than fantastic food" (Interview 29).

\subsubsection{Sensory Experiences}

Senses of vision, taste, and smell collaborate to create sensory experiences of food, and interviewees mentioned having increased sensory awareness linked to their improved health. Membership in CSA means that the vegetables are seasonal and freshly harvested and participants expressed how they enjoy tasting the produce: "And the flavors, not to mention, the flavors one tastes are fantastic, my husband always says" (Interview 7). Experiences with vegetables evolved as people received new kinds of vegetables and CSA provided the information needed to identify them. Participants recognized new items, new tastes, especially in the first period of membership: "I now know things and tastes-that I had never heard of before" (Interview 28). Some participants indicated a conscious evaluation of their own sensory skills, as they enjoy tasting: "Oh my God, how delicious these vegetables are and our taste has started to return to something normal, when actually these are just the tastes of raw vegetables" (Interview 25). Visual experiences were also recounted, especially when people receive the whole vegetable box by pick-up or when they unload vegetables from the box at home: "So, I really bring home the vegetables and then I look at it and it makes me so happy that they are so beautiful and they look so good" (Interview 12). Most interviewees strongly valued the smell of vegetables, when using items: "I put it in the fridge and used it for weeks, until it had all gone, I always added a little to all my meals and it made a lovely smell throughout the whole house" (Interview 17).

\subsection{Psychological Well-Being: The Experiences of Investing in Efforts to Master Food-Tasks}

Changing the food source seems to be an obvious transition for the members interviewed. Maintaining the CSA membership refers to the inner processes that facilitate a member's ability to invest in efforts to master tasks successfully and to reduce inconveniences. CSA provides space for ongoing psychological growth and integrity as a support for psychological well-being.

\subsubsection{Personal Learning}

Among the interviewees, a variety of developments were described. Many interviewees have reported some sort of change in their practices: "It was then I learned pretty much what to do and when, and if I already had some knowledge, it was deepened" (Interview 29). A number of interviewees commented that participation empowered them to learn new abilities in managing food consumption: "I learned the way of processing Swiss chard, but I also learned how to process many others. ... . I'm sure it all contributed to me becoming more aware of what we eat, what we drink, what we cook..." (Interview 19). Through participation in CSA, they were able to learn to make new food choices: "I wouldn't have thought that Brussels sprouts were delicious raw, I never would have thought that" (Interview 24). Interviewees living in families mentioned that CSA allowed their family to learn about how they get their food as well as how it is grown: "Our children ... know where everything comes from. That knowledge is sure to have come from here. This is part of life how we get these things" (Interview 31). Interestingly, interviewees mentioned that they have become more aware of agricultural issues and organic farming: "I also learned a lot from them about how to grow vegetables organically" (Interview 10).

\subsubsection{Prospering due to Food-Related Challenges}

Many interviewees indicated that consuming CSA vegetables sometimes seems to be a challenge (e.g., cooking food from scratch successfully). Accordingly, food consumption associated with CSA implied dealing with food processes: "I'm really sorry to throw things out, I use every last piece" (Interview 9) and dealing with concrete challenges: "It's a challenge, yes, this inconvenience is there, and I will not let CSA vegetables get damaged in the fridge "(Interview 1). Incorporating CSA items into the diet, in contrast 
to earlier consumption practices, related to personal capacity: "I've totally decided that it is what I eat. Now I'm really at that point that I do not eat from other food sources and I can manage it. The contrast is pretty big" (Interview 18). Personal hurdles could be overcome where interviewees had confidence in their ability to consume CSA food: "There are always flour and onions at home, and finally you can always eat something [cooking from scratch]" (Interview 3). They expressed effectiveness in different food-related tasks, as e.g., storage: "I squeeze the air out of the boxes and then I could store them in fresh form for 4-5 days" (Interview 20), or that home-cooking is even explicitly loaded with positive emotions: "And I managed it too. I baked it... I can change and revive every CSA vegetable, and then it's pretty fine to eat" (Interview 35).

Effectively dealing with CSA difficulties is crucial to continued membership: "I am persistent, I have carried out CSA well-from the beginning" (Interview 11). Interviewees mentioned that they had to adjust their personal behavior but highlighted they need capacity to engage consistently without becoming distracted: "I have no problem with that, and I can accept it this way" (Interview 33). Self-efficacy provides an important feeling of presence and stability regarding CSA: "Obviously, there are moments when you think about whether it's worth being here every week [to take part in CSA], or when you do not know what to do with vegetables. But whatever happened, I never considered leaving it" (Interview 17).

\subsection{Social Well-Being: The Experience of Closer Interactions Related to Food}

CSA food is strongly embedded in a community-based environment involving interactions and social relationships. CSA provided venues for pick-ups or farm visits where community members could come together. Interviewees mentioned that CSA widened their social realities through the very different modes of the production/consumption relationship and expanded their horizons regarding social connections in consumption. To belong to a CSA from a social well-being point of view implies the social tasks encountered: Experiencing relatedness and connections with other members.

\subsubsection{Sense of Community Belonging}

Interviewees reported they have the feeling of being part of a larger stable structure, and CSA encouraged them to encompass a broad range of activities, interests, and emotions through group belonging. For interviewees, participation provided the valuable social patterns they highlighted: "from both participants and farmers ... so they show this openness and the friendship and helpfulness" (Interview 4). As participants all received the same vegetable boxes on the same day of the week it generated a point of group belonging: "There is a sense of community belonging thing here. This means that not the whole world gets these vegetables, but these 60 people get them here: they take them out of the box, and they all have the same item such as chickweed" (Interview 8). They realized that other members might think similarly to them in relation to local food consumption: "And when I go on Thursdays... I meet a lot of the same faces who I feel close to. We don't meet very often, but we think the same way" (Interview 17). Community events, such as farm visits, pick-up times, or decisions regarding seasonal planning gave an opportunity for them to feel recognized on behalf of the CSA community. This sense of belonging provided them with possibilities to shape their decision making: "This is an open and interactive system, even if somebody does not want to speak" (Interview 11). CSA prompted and initiated personal investment into how to be active in a community as well: "I'm going to try to organize a Vác pick-up point but it's really hard. I need to figure out a way for me to be more active in this. Now it's more of a problem that, for example, somebody forgets to come for vegetables, or can't come for it, or knows he can't come. I should find common solutions for it" (Interview 5). Moreover, interviewees expressed that the way they use CSA vegetables at home increases a sense of belonging in the family. Cooking and sharing CSA food influenced their family-related food consumption, their connection to the family: "and become even more aware of how this [CSA vegetables] builds up the family community" (Interview 23).

\subsubsection{Expanding Social Relations}

CSA facilitates people to build new social connections. Participation further strengthens relations among consumers: "I have a friendly relationship with fifteen people-say 5-10 mostly women - in our CSA. 
We call each other; we go to a concert together or meet in other ways. The relationships built a network.... There are very strong relationships" (Interview 26). Social relations can also be formed within CSA through increased interaction between farmers and participants. CSA members often feel very close to farmers: "I always ask her [farmer] what difficulty she is in or what I can do for her now" (Interview 20). Interestingly, interviewees made a number of comments that CSA facilitates relationships with acquaintances in order to avoid food waste: "There's so much [vegetables] to eat and I just cannot eat that much. I've already realized that I am inviting guests to social events and dinner parties just to use up all the vegetables" (Interview 24) or shrink surpluses, etc.: "I got a box of vegetables and I saw that I didn't have time to do anything with them. I went to Tai Chi and after the training I said: you can pick them, take them, take them home. I said this is from CSA and it's organic" (Interview 8).

\subsection{Spiritual Well-Being: Widened Sense of Food-Related Experiences}

Participants' descriptions highlighted that CSA creates a space where they can live with a spiritual perspective. Their experiences centered on the opportunity given to CSA participation in "fronting up" on the issue of local, organic farming, or the care CSA participation provided for them. Spiritual well-being focuses on aspects of a wider life orientation towards noticing or appreciating aspects of CSA membership.

\subsubsection{Devotion to Food Consumption}

Devotion to Food Consumption emerged as a theme referring to food relations, which are more than pure market-based consumption. Due to the proximity between farmland and participants, growing, distributing, and consuming local food became both accessible and understandable for interviewees. They highlighted the shift away from the pure utility of food consumption: "It is a promotion of a philosophy that does not just buy these vegetables; it is coupled with other buying habits and attitudes" (Interview 27). CSA participants engaged with seasons, nature, and the land directly in a tactile form to which they attribute a form of meaning: "Even so, with the seasons the seasonality somehow changed what I experienced. Yes, what I experienced as a member through vegetables is kind of like the rhythm of nature, harmony" (Interview 4). Interviewees expressed that the attachment to small scale producers also implied spiritual closeness to nature and the planet. This was vital for them; it was about "fronting up" on the issue of local food origin, organic farming, and farmers: "They're working with vegetables and I know there's a lot of work behind it. For some reason, this task has been given to them in order to help people here on Earth" (Interview 21). Moreover, they mentioned several sets of fixed actions, as rituals, when they even celebrate food: "The pick-up day is Thursday.... So, every Thursday night everyone gathers around the table and rub their hands with their mouth watering at all the wonderful delicacies there" (Interview 14).

\subsubsection{Gratitude}

Gratitude emerged as interviewees highlighted that they are blessed. This theme reveals participants' appreciation and recognition of the personal attention CSA participation provided for them: "We received a gift from nature that this is available" (Interview 2). The direct connection between farmers and members is an important source to allow for noticing and appreciating the positivity in CSA food: "so I used to talk to the farmer, and I am very grateful that she brought me such fantastic vegetables" (Interview 28). They emphasized the importance to express gratitude in particular situations: "I sent a letter [via the CSA email-list] with the topic: CSA participation is about our common delight. Then we got peppers, green peppers for the first time. I really did taste it, the taste of my childhood and the taste of summer. Then I wrote a poem: Ode to Green Peppers. With this I strengthened our enjoyment of it, how much goodness we have [here in CSA]" (Interview 23). In addition, enjoyment of benefits in relation to CSA food might be experienced from having access to quality food: "Non-chemical vegetables are certainly a more viable alternative" (Interview 26) to spiritual fulfillment: "Maybe there is a vegetable spirit ... a kind of heart and soul in relation to CSA " (Interview 21). 


\section{Discussion}

Sustainability is a combination of economic, and social aspects of food supply chains, which can enable new food consumption models in AFNs [2,90]. Indeed, promoting local economic solutions and addressing certain sustainability issues shapes agriculture in order to preserve or renew interactions between consumers and producers. Not only are these important options for building sustainable community economic development [91] but they can affect the experiential relationships between consumers and their food. Trust and cooperation manifested in transparent farm operations and farming are fundamental in relationships between consumers and producers who are "disconnected from food production and processes associated with food moving from farm to plate" [92] (p. 8). CSA provides an opportunity to improve sustainable consumption patterns and this research discovered how consumers establish a pleasurable relationship with the food they buy.

Beyond a relation to healthy nutrition, the effect of food on well-being has been a growing topic of research interest [39]. This paper examined food-related well-being in CSAs and explored the extent to which participants' experiences and outcomes relate to it. In this context, however, there is a need for a multiparadigmatic view containing all the aspects of a person's life that may contribute to their perceived well-being.

Many of the positive outcomes of how the physical, psychological, social, and spiritual domains of the BPSS model help maintain CSA participation corroborated previous findings. People enjoy the physical aspects of food, such as flavor, variety, freshness, and improved nutrition. Other personal benefits that can be linked to the well-being of individuals are the committed nature of CSA farm deliveries helping to enforce healthy dietary choices and improve health outcomes of participating individuals $[18,93,94]$. From a psychological aspect, belonging to a CSA offers people opportunities to prove their efficacy; facilitating behaviors and habits in line with the needs of the maintenance of healthy eating, and inspiring them to learn about agriculture and food cultivation practices. CSA empowers people to pursue activities such as food preparation and new ways of cooking or storing food [59], which might result in a more holistic relationship to food.

As Rossi et al. [25] (p. 17) suggest, "The CSA experience entangles food related behavior in a broader array of social relationships". From a social perspective CSA increases contact between members (farmers, participants) and belonging to a small consumer group facilitates the flourishing of interpersonal resources. Moreover, sharing recipes or even food with friends and neighbors, which is frequent in CSA, is a pleasant time to socially interact with other people. In this way, CSA promotes a sense of relatedness and strengthens the consumer-producer and urban-rural relationship, offering people more enjoyment in their lives.

From the results, it appears that components that were not previously highlighted in the food-related well-being literature have been identified, such as consumers' spiritual concerns. Food-related spiritual experiences map the significant connection with food as well as the greater relational understanding of food. CSA food consumption holds potential benefits when it comes to spirituality. CSA participants with their environmentally-friendly product choice are concerned about the environment and nature, and show appreciation for food which is in line with their actions $[81,91,95,96]$.

This study stresses the relevance of psychological, social, and spiritual aspects of food-related well-being beyond the nutritional characteristics of food. Clearly, CSA participation does not provide individuals with the ability to constantly feel good. There are various arguments both in favor and against CSA participation from a personal perspective as CSA consumption may underlie a broad range of experiences. At the same time, it is possible that members may be encouraged to accept CSAs due to the emerging well-being benefits. Consideration of how consumers perceive the effects of food on their well-being can lead to a better understanding of consumers' food choices and to the creation of effective strategies to improve the food patterns of consumers or to map the background of healthy eating patterns. Our study contributes to a better understanding of the world of CSAs and consumers in these alternative systems. As Savarese et al. [2] emphasized in their similar study focusing on CSA 
practices in New Zealand, the recognition of alternative agricultural methods may lead to a better promotion of sustainable food practices. The understanding of food-related well-being in this context can add to knowledge generation in this field.

\section{Limitations, Future Studies}

Outcomes of the present work provide an insight into consumers' experience of well-being in a food-related context. Despite the contributions of this study, some limitations are worth mentioning for future research. One limitation is that neither the individuals' prior characteristics of well-being, nor the baseline stage of a CSA diet have been controlled for in the present study. A further limitation is that this research has been conducted in a specific (Eastern-European) region and results might be bound to the socio-cultural background of that region.

Therefore, future studies should focus on samples from other countries including using a larger sample, valuable for conducting cross-cultural comparisons. Future research should include longitudinal examinations of where the changes of well-being-from the very beginning of CSA membership—can be analyzed.

This study is novel in its inclusion of CSA members in relation to food-related well-being; however, it would be valuable to examine whether these results are unique to CSA or if they could be applied to any form of AFN or farm market setting. In line with this there is a need for more comparative food system values-within CSA across cultures and across CSA/non-CSA consumers. In further studies, it would be worthwhile to investigate the role of different AFN environments, the motivational background of the members, and the individual characteristics (including age and gender) that maintain different aspects of health. It would be appropriate to suggest that constructs and measures for the spirituality aspects of the BPSS model merit further development and could potentially reveal interesting contrasts-especially in the context where comparative consumer groups could be studied. An interesting question which could be part of further studies is how religiousness (a close construct to spirituality) might relate to all four well-being aspects of BPSS in connection to alternative consumption.

Another topic for possible investigation could be what happens when the CSA framework is no longer in place in a person's life: It is a question of how food-related well-being changes and influences individuals' further consumption. Further qualitative research focusing more on the producer side could help provide a more complete picture of the CSA experience-particularly in relation to the concept of sustainable well-being.

\section{Conclusions}

This research specifies the importance and the centrality of the consumer related approach established in food-related well-being. Sustainable agricultural practices provide a fresh perspective, inviting reflection on opportunities to improve economic, environmental, and social well-being and adding to the quality of life in relation to food. This might strengthen a new axis of reflection on what is acceptable for individuals in their food environment. These results are important in convincing people that their food-related experiences belong to their perceived well-being as well as stimulating people to elevate their multidimensional expectations in relation to food.

It seems that food-related well-being is firmly linked to locally produced food consumption [97]. In this view, food-related well-being is seen as value-laden and socially determined. Maintaining a valuable set of relationships regarding a person's relation to food and agriculture practices might contribute to sustainability and perceived well-being.

Author Contributions: Conceptualization, I.L.B., A.B., and A.O.; methodology, I.L.B.; validation, J.R.; formal analysis, I.L.B.; investigation, I.L.B.; resources, I.L.B.; data curation, I.L.B.; writing—original draft preparation, I.L.B.; writing-review and editing, I.L.B., A.B., G.B., Á.N., A.R., and J.R.; visualization, I.L.B.; supervision, A.R. and G.B.; project administration, I.L.B.; funding acquisition, I.L.B. and J.R. All authors have read and agreed to the published version of the manuscript. 
Funding: This work was supported by a Research Fund of the Doctoral School of Psychology at the Faculty of Education and Psychology, ELTE Eötvös Loránd University.

Conflicts of Interest: The authors declare no conflict of interest.

\section{References}

1. Story, M.; Kaphingst, K.M.; Robinson-O'Brien, R.; Glanz, K. Creating Healthy Food and Eating Environments: Policy and Environmental Approaches. Annu. Rev. Public Health 2008, 29, 253-272. [CrossRef] [PubMed]

2. Savarese, M.; Chamberlain, K.; Graffigna, G. Co-Creating Value in Sustainable and Alternative Food Networks: The Case of Community Supported Agriculture in New Zealand. Sustainability 2020, $12,1252$. [CrossRef]

3. Autio, M.; Collins, R.; Wahlen, S.; Anttila, M. Consuming nostalgia? The appreciation of authenticity in local food production. Int. J. Consum. Stud. 2013, 37, 564-568. [CrossRef]

4. Rozin, P. The Meaning of Food in Our Lives: A Cross-Cultural Perspective on Eating and Well-Being. J. Nutr. Educ. Behav. 2005, 37, S107-S112. [CrossRef]

5. Venhoeven, L.A.; Bolderdijk, J.W.; Steg, L. Explaining the Paradox: How Pro-Environmental Behaviour can both Thwart and Foster Well-Being. Sustainability 2013, 5, 1372-1386. [CrossRef]

6. Grunert, K.G.; Dean, M.; Raats, M.M.; Nielsen, N.A.; Lumbers, M. A measure of satisfaction with food-related life. Appetite 2007, 49, 486-493. [CrossRef]

7. Schnettler, B.; Miranda-Zapata, E.; Sánchez, M.; Grunert, K.G.; Lobos, G.; Adasme-Berríos, C.; Orellana, L.; Sepúlveda, J.; Hueche, C. Measurement invariance in the Satisfaction with Food-related Life scale: A comparison of Chilean and Spanish university students. Food Qual. Prefer. 2017, 57, 79-86. [CrossRef]

8. Block, L.G.; Grier, S.A.; Childers, T.L.; Davis, B.; Ebert, J.E.J.; Kumanyika, S.; Laczniak, R.N.; Machin, J.E.; Motley, C.M.; Peracchio, L.; et al. From Nutrients to Nurturance: A Conceptual Introduction to Food Well-Being. J. Public Policy Mark. 2011, 30, 5-13. [CrossRef]

9. Ares, G.; De Saldamando, L.; Giménez, A.; Deliza, R. Food and wellbeing. Towards a consumer-based approach. Appetite 2014, 74, 61-69. [CrossRef]

10. Ares, G.; de Saldamando, L.; Giménez, A.; Claret, A.; Cunha, L.M.; Guerrero, L.; de Moura, A.P.; Oliveira, D.C.R.; Symoneaux, R.; Deliza, R. Consumers' associations with wellbeing in a food-related context: A cross-cultural study. Food Qual. Prefer. 2015, 40, 304-315. [CrossRef]

11. Ares, G.; Giménez, A.; Vidal, L.; Zhou, Y.; Krystallis, A.; Tsalis, G.; Symoneaux, R.; Cunha, L.M.; de Moura, A.P.; Claret, A.; et al. Do we all perceive food-related wellbeing in the same way? Results from an exploratory cross-cultural study. Food Qual. Prefer. 2016, 52, 62-73. [CrossRef]

12. Goodman, D.; Goodman, M.K. Alternative Food Networks. In International Encyclopedia of Human Geography; Kitchin, R., Thrift, N., Eds.; Elsevier: Oxford, UK, 2009; Volume 4, pp. 208-220. ISBN 978-0-08-044910-4.

13. Low, S.A.; Adalja, A.; Beaulieu, E.; Key, N.; Martinez, S.; Melton, A.; Perez, A.; Ralston, K.; Stewart, H.; Suttles, S.; et al. Trends in U.S. Local and Regional Food Systems: A Report to Congress; U.S. Department of Agriculture, Economic Research Service: Washington, DC, USA, 2015; p. 92.

14. European CSA Research Group. Overview of Community Supported Agriculture in Europe; CSA for Europe Report; Urgenci: Aubagne, France, 2016; p. 138.

15. Som Castellano, R.L. Alternative Food Networks and the Labor of Food Provisioning: A Third Shift? Rural Sociol. 2016, 81, 445-469. [CrossRef]

16. Neulinger, A.; Bársony, F.; Gjorevska, N.; Lazányi, O.; Pataki, G.; Takács, S.; Török, A. Engagement and subjective well-being in alternative food networks: The case of Hungary. Int. J. Consum. Stud. 2020, 1-10. [CrossRef]

17. Hinrichs, C.C. Embeddedness and local food systems: Notes on two types of direct agricultural market. J. Rural Stud. 2000, 16, 295-303. [CrossRef]

18. Wharton, C.M.; Hughner, R.S.; MacMillan, L.; Dumitrescu, C. Community Supported Agriculture Programs: A Novel Venue for Theory-Based Health Behavior Change Interventions. Ecol. Food Nutr. 2015, 54, $280-301$. [CrossRef]

19. Zoll, F.; Specht, K.; Opitz, I.; Siebert, R.; Piorr, A.; Zasada, I. Individual choice or collective action? Exploring consumer motives for participating in alternative food networks. Int. J. Consum. Stud. 2018, 42, 101-110. [CrossRef] 
20. Galt, R.E.; Van Soelen Kim, J.; Munden-Dixon, K.; Christensen, L.O.; Bradley, K. Retaining Members of Community Supported Agriculture (CSA) in California for Economic Sustainability: What Characteristics Affect Retention Rates? Sustainability 2019, 11, 2489. [CrossRef]

21. Rossi, A. Beyond Food Provisioning: The Transformative Potential of Grassroots Innovation around Food. Agriculture 2017, 7, 6. [CrossRef]

22. Samoggia, A.; Perazzolo, C.; Kocsis, P.; Del Prete, M. Community Supported Agriculture Farmers' Perceptions of Management Benefits and Drawbacks. Sustainability 2019, 11, 3262. [CrossRef]

23. Allen, J.E., IV; Rossi, J.; Woods, T.A.; Davis, A.F. Do Community Supported Agriculture programmes encourage change to food lifestyle behaviours and health outcomes? New evidence from shareholders. Int. J. Agric. Sustain. 2017, 15, 70-82. [CrossRef]

24. Cohen, J.N.; Gearhart, S.; Garland, E. Community Supported Agriculture: A Commitment to a Healthier Diet. J. Hunger Environ. Nutr. 2012, 7, 20-37. [CrossRef]

25. Rossi, J.J.; Woods, T.A.; Allen IV, J.E. Impacts of a Community Supported Agriculture (CSA) Voucher Program on Food Lifestyle Behaviors: Evidence from an Employer-Sponsored Pilot Program. Sustainability 2017, 9, 1543. [CrossRef]

26. United Nations. Special Edition: Progress towards the Sustainable Development Goals: Report of the Secretary-General; United Nations, Economic and Social Council: New York, NY, USA, 2019; p. 39.

27. Engel, G.L. The Need for a New Medical Model: A Challenge for Biomedicine. Science 1977, 197, 129-136. [CrossRef] [PubMed]

28. WHO. What is the WHO definition of health? Available online: https://www.who.int/about/who-we-are/ frequently-asked-questions (accessed on 20 January 2020).

29. Saad, M.; de Medeiros, R.; Mosini, A.C. Are We Ready for a True Biopsychosocial-Spiritual Model? The Many Meanings of "Spiritual". Medicines 2017, 4, 79. [CrossRef]

30. Pargament, K.I. The Psychology of Religion and Coping: Theory, Research, Practice, 1st ed.; Guilford Press: New York, NY, USA, 1997; ISBN 978-1-57230-214-3.

31. Rumbold, B.D. A review of spiritual assessment in health care practice. Med. J. Aust. 2007, 186, S60-S62. [CrossRef]

32. Hatala, A.R. Towards a Biopsychosocial-Spiritual Approach in Health Psychology: Exploring Theoretical Orientations and Future Directions. J. Spiritual. Ment. Health 2013, 15, 256-276. [CrossRef]

33. Toussaint, L.L.; Worthington, E.L.; Williams, D.R. Forgiveness and Health: Scientific Evidence and Theories Relating Forgiveness to Better Health, 1st ed.; Springer: Dordrecht, the Netherlands, 2015; ISBN 978-94-017-9993-5.

34. Prest, L.A.; Robinson, W.D. Systemic Assessment and Treatment of Depression and Anxiety in Families: The BPSS Model in Practice. J. Syst. Ther. 2006, 25, 4-24. [CrossRef]

35. Morandi, A.; Nambi, A.N.N.; Fave, A.D. Joining Knowledge Traditions: Towards an Integrated Approach to Health and Well-Being. In An Integrated View of Health and Well-Being; Morandi, A., Nambi, A.N.N., Eds.; Cross-Cultural Advancements in Positive Psychology; Springer: Dordrecht, the Netherland, 2013; volume 11, pp. 189-195. ISBN 978-94-007-6688-4.

36. Huber, M.; van Vliet, M.; Giezenberg, M.; Winkens, B.; Heerkens, Y.; Dagnelie, P.C.; Knottnerus, J.A. Towards a 'patient-centred' operationalisation of the new dynamic concept of health: A mixed methods study. BMJ Open 2016, 6, e010091. [CrossRef]

37. Sulmasy, D.P. A Biopsychosocial-Spiritual Model for the Care of Patients at the End of Life. Gerontologist 2002, 42, 24-33. [CrossRef]

38. Chamberlain, K. Food and Health: Expanding the Agenda for Health Psychology. J. Health Psychol. 2004, 9, 467-481. [CrossRef]

39. Holder, M.D. The Contribution of Food Consumption to Well-Being. Ann. Nutr. Metab. 2019, 74, 44-51. [CrossRef] [PubMed]

40. Dietary Guidelines for Americans 2015-2020; U.S. Department of Health and Human Services and U.S. Department of Agriculture: Washington, DC, USA, 2015.

41. Vasquez, A.; Sherwood, N.E.; Larson, N.; Story, M. Community-Supported Agriculture as a Dietary and Health Improvement Strategy: A Narrative Review. J. Acad. Nutr. Diet. 2017, 117, 83-94. [CrossRef] [PubMed] 
42. Hanson, K.L.; Kolodinsky, J.; Wang, W.; Morgan, E.H.; Pitts, S.B.J.; Ammerman, A.S.; Sitaker, M.; Seguin, R.A. Adults and Children in Low-Income Households that Participate in Cost-Offset Community Supported Agriculture Have High Fruit and Vegetable Consumption. Nutrients 2017, 9, 726. [CrossRef] [PubMed]

43. Minaker, L.M.; Raine, K.D.; Fisher, P.; Thompson, M.E.; Van Loon, J.; Frank, L.D. Food Purchasing From Farmers' Markets and Community-Supported Agriculture Is Associated With Reduced Weight and Better Diets in a Population-Based Sample. J. Hunger Environ. Nutr. 2014, 9, 485-497. [CrossRef]

44. Miller, V.; Mente, A.; Dehghan, M.; Rangarajan, S.; Zhang, X.; Swaminathan, S.; Dagenais, G.; Gupta, R.; Mohan, V.; Lear, S.; et al. Fruit, vegetable, and legume intake, and cardiovascular disease and deaths in 18 countries (PURE): A prospective cohort study. Lancet 2017, 390, 2037-2049. [CrossRef]

45. Wang, X.; Ouyang, Y.; Liu, J.; Zhu, M.; Zhao, G.; Bao, W.; Hu, F.B. Fruit and vegetable consumption and mortality from all causes, cardiovascular disease, and cancer: Systematic review and dose-response meta-analysis of prospective cohort studies. BMJ 2014, 349, g4490. [CrossRef]

46. Asher, G.; Sassone-Corsi, P. Time for Food: The Intimate Interplay between Nutrition, Metabolism, and the Circadian Clock. Cell 2015, 161, 84-92. [CrossRef]

47. Crispim, C.A.; Zimberg, I.Z.; dos Reis, B.G.; Diniz, R.M.; Tufik, S.; de Mello, M.T. Relationship between Food Intake and Sleep Pattern in Healthy Individuals. J. Clin. Sleep Med. 2011, 7, 659-664. [CrossRef]

48. Park, J.-H.; Kim, S.-H.; Lee, M.S.; Kim, M.-S. Epigenetic modification by dietary factors: Implications in metabolic syndrome. Mol. Aspects Med. 2017, 54, 58-70. [CrossRef]

49. Aertsens, J.; Mondelaers, K.; Verbeke, W.; Buysse, J.; Van Huylenbroeck, G. The influence of subjective and objective knowledge on attitude, motivations and consumption of organic food. Br. Food J. 2011, 113, 1353-1378. [CrossRef]

50. Vega-Zamora, M.; Parras-Rosa, M.; Murgado-Armenteros, E.M.; Torres-Ruiz, F.J. The Influence of the Term 'Organic' on Organic Food Purchasing Behavior. Procedia-Soc. Behav. Sci. 2013, 81, 660-671. [CrossRef]

51. Brookie, K.L.; Best, G.I.; Conner, T.S. Intake of Raw Fruits and Vegetables Is Associated With Better Mental Health Than Intake of Processed Fruits and Vegetables. Front. Psychol. 2018, 9, 487. [CrossRef]

52. Jyväkorpi, S.K.; Urtamo, A.; Pitkälä, K.H.; Strandberg, T.E. Happiness of the oldest-old men is associated with fruit and vegetable intakes. Eur. Geriatr. Med. 2018, 9, 687-690. [CrossRef]

53. Warner, R.M.; Frye, K.; Morrell, J.S.; Carey, G. Fruit and Vegetable Intake Predicts Positive Affect. J. Happiness Stud. 2017, 18, 809-826. [CrossRef]

54. Blanchflower, D.G.; Oswald, A.J.; Stewart-Brown, S. Is psychological well-being linked to the consumption of fruit and vegetables? Working Paper. Soc. Indic. Res. 2013, 114, 785-801. [CrossRef]

55. Conner, T.S.; Brookie, K.L.; Richardson, A.C.; Polak, M.A. On carrots and curiosity: Eating fruit and vegetables is associated with greater flourishing in daily life. Br. J. Health Psychol. 2015, 20, 413-427. [CrossRef]

56. Bishwajit, G.; O'Leary, D.P.; Ghosh, S.; Sanni, Y.; Shangfeng, T.; Zhanchun, F. Association between depression and fruit and vegetable consumption among adults in South Asia. BMC Psychiatry 2017, 17, 15. [CrossRef]

57. Nguyen, B.; Ding, D.; Mihrshahi, S. Fruit and vegetable consumption and psychological distress: Cross-sectional and longitudinal analyses based on a large Australian sample. BMJ Open 2017, 7, e014201. [CrossRef]

58. Mujcic, R.; Oswald, A.J. Evolution of Well-Being and Happiness After Increases in Consumption of Fruit and Vegetables. Am. J. Public Health 2016, 106, 1504-1510. [CrossRef]

59. Birtalan, I.L.; Neulinger, Á.; Rácz, J.; Bárdos, G. Community supported agriculture membership: The benefits of spousal involvement. Int. J. Consum. Stud. 2020, 44, 172-180. [CrossRef]

60. Bublitz, M.G.; Hansen, J.; Peracchio, L.A.; Tussler, S. Hunger and Food Well-Being: Advancing Research and Practice. J. Public Policy Mark. 2019, 38, 136-153. [CrossRef]

61. Zhou, G.; Gan, Y.; Hamilton, K.; Schwarzer, R. The Role of Social Support and Self-efficacy for Planning Fruit and Vegetable Intake. J. Nutr. Educ. Behav. 2017, 49, 100-106. [CrossRef] [PubMed]

62. Hoerster, K.D.; Wilson, S.; Nelson, K.M.; Reiber, G.E.; Masheb, R.M. Diet quality is associated with mental health, social support, and neighborhood factors among Veterans. Eat. Behav. 2016, 23, 168-173. [CrossRef] [PubMed]

63. Rieffestahl, A.M. Super-Healthy Families: Alternative Food Habits and their Social Implications. Food Cult. Soc. 2014, 17, 615-627. [CrossRef]

64. Wang, M.C.; Naidoo, N.; Ferzacca, S.; Reddy, G.; Van Dam, R.M. The Role of Women in Food Provision and Food Choice Decision-Making in Singapore: A Case Study. Ecol. Food Nutr. 2014, 53, 658-677. [CrossRef] 
65. Merle, A.; Herault-Fournier, C.; Werle, C.O.C. The effects of indication of local geographical origin on food perceptions. Rech. Appl. Eng. Mark. Engl. Ed. 2016, 31, 26-42. [CrossRef]

66. Zepeda, L.; Deal, D. Organic and local food consumer behaviour: Alphabet Theory. Int. J. Consum. Stud. 2009, 33, 697-705. [CrossRef]

67. Lee, H.-J. Does Consumption of Organic Foods Contribute to Korean Consumers' Subjective Well-Being? Sustainability 2019, 11, 5496. [CrossRef]

68. Puchalski, C.M.; Vitillo, R.; Hull, S.K.; Reller, N. Improving the Spiritual Dimension of Whole Person Care: Reaching National and International Consensus. J. Palliat. Med. 2014, 17, 642-656. [CrossRef]

69. Arbit, N.; Ruby, M.; Rozin, P. Development and validation of the meaning of food in life questionnaire (MFLQ): Evidence for a new construct to explain eating behavior. Food Qual. Prefer. 2017, 59, 35-45. [CrossRef]

70. King, S.C.; Snow, J.; Meiselman, H.L.; Sainsbury, J.; Carr, B.T.; McCafferty, D.; Serrano, D.; Gillette, M.; Millard, L.; Li, Q. Development of a questionnaire to measure consumer wellness associated with foods: The WellSense Profile ${ }^{\mathrm{TM}}$. Food Qual. Prefer. 2015, 39, 82-94. [CrossRef]

71. Meiselman, H.L. Quality of life, well-being and wellness: Measuring subjective health for foods and other products. Food Qual. Prefer. 2016, 54, 101-109. [CrossRef]

72. Bublitz, M.G.; Peracchio, L.A.; Andreasen, A.R.; Kees, J.; Kidwell, B.; Miller, E.G.; Motley, C.M.; Peter, P.C.; Rajagopal, P.; Scott, M.L.; et al. Promoting positive change: Advancing the food well-being paradigm. J. Bus. Res. 2013, 66, 1211-1218. [CrossRef]

73. Goetzke, B.; Nitzko, S.; Spiller, A. Consumption of organic and functional food. A matter of well-being and health? Appetite 2014, 77, 94-103. [CrossRef] [PubMed]

74. Goetzke, B.I.; Spiller, A. Health-improving lifestyles of organic and functional food consumers. Br. Food J. 2014, 116, 510-526. [CrossRef]

75. Bliss, S. The Case for Studying Non-Market Food Systems. Sustainability 2019, 11, 3224. [CrossRef]

76. Tuttle, W.M. The World Peace Diet: Eating for Spiritual Health and Social Harmony, 1st ed.; Lantern Books: New York, NY, USA, 2005; ISBN 978-1-59056-083-9.

77. Busch, L. Individual choice and social values: Choice in the agrifood sector. J. Consum. Cult. 2016, 16, 124-143. [CrossRef]

78. Sarmiento, E.R. Synergies in alternative food network research: Embodiment, diverse economies, and more-than-human food geographies. Agric. Hum. Values 2017, 34, 485-497. [CrossRef]

79. Michopoulou, E.; Jauniškis, P. Exploring the relationship between food and spirituality: A literature review. Int. J. Hosp. Manag. 2020, 87, 102494. [CrossRef]

80. Delaney, C. The Spirituality Scale: Development and Psychometric Testing of a Holistic Instrument to Assess the Human Spiritual Dimension. J. Holist. Nurs. 2005, 23, 145-167. [CrossRef]

81. Ravenscroft, N.; Moore, N.; Welch, E.; Hanney, R. Beyond agriculture: The counter-hegemony of community farming. Agric. Hum. Values 2013, 30, 629-639. [CrossRef]

82. Balázs, B.; Pataki, G.; Lazányi, O. Prospects for the future: Community supported agriculture in Hungary. Futures 2016, 83, 100-111. [CrossRef]

83. Jehlička, P.; Kostelecký, T.; Smith, J. Food Self-Provisioning in Czechia: Beyond Coping Strategy of the Poor: A Response to Alber and Kohler's 'Informal Food Production in the Enlarged European Union' (2008). Soc. Indic. Res. 2013, 111, 219-234. [CrossRef]

84. OECD Better Life Index. Available online: http://www.oecdbetterlifeindex.org/countries/hungary/ (accessed on 25 March 2020).

85. Balázs, B. Local Food System Development in Hungary. Int. J. Sociol. Agric. Food 2012, 19, 403-421.

86. Tudatos Vásárlók Egyesülete Múködő Közösségi Gazdaságok, Dobozrendszerek és Bevásárlóközösségek [Operating Community Supported Agricultures, Box Systems and Solidarity Purchasing Groups in Hungary]. Available online: https:/tudatosvasarlo.hu/cikk/mukodo-kozossegi-mezogazdasagi-csoportokbevasarlokozossegek (accessed on 21 October 2019).

87. Bunniss, S.; Kelly, D.R. Research paradigms in medical education research. Med. Educ. 2010, 44, $358-366$. [CrossRef]

88. Palinkas, L.A.; Horwitz, S.M.; Green, C.A.; Wisdom, J.P.; Duan, N.; Hoagwood, K. Purposeful Sampling for Qualitative Data Collection and Analysis in Mixed Method Implementation Research. Adm. Policy Ment. Health Ment. Health Serv. Res. 2015, 42, 533-544. [CrossRef] 
89. Braun, V.; Clarke, V. Using thematic analysis in psychology. Qual. Res. Psychol. 2006, 3, 77-101. [CrossRef]

90. Paloviita, A. Consumers' Sustainability Perceptions of the Supply Chain of Locally Produced Food. Sustainability 2010, 2, 1492-1509. [CrossRef]

91. Sumner, J. Eating Our Way to Sustainability? Leisure, Food and Community Economic Development. Sustainability 2018, 10, 1422. [CrossRef]

92. Uhlmann, K.; Lin, B.B.; Ross, H. Who Cares? The Importance of Emotional Connections with Nature to Ensure Food Security and Wellbeing in Cities. Sustainability 2018, 10, 1844. [CrossRef]

93. Griffin, M.K.; Sobal, J. Consumer Food System Participation: A Community Analysis. Ecol. Food Nutr. 2014, 53, 579-595. [CrossRef] [PubMed]

94. Harmon, A.H. Community Supported Agriculture: A Conceptual Model of Health Implications. Austin J. Nutr. Food Sci. 2014, 2, 1024.

95. Kis, B. Community-supported agriculture from the perspective of health and leisure. Ann. Leis. Res. 2014, 17, 281-295. [CrossRef]

96. Xiao, J.J.; Li, H. Sustainable Consumption and Life Satisfaction. Soc. Indic. Res. 2011, 104, 323-329. [CrossRef]

97. Bharucha, Z.P.; Weinstein, N.; Watson, D.; Boehm, S. Participation in local food projects is associated with better psychological well-being: Evidence from the East of England. J. Public Health 2019, 42, e187-e197. [CrossRef] [PubMed]

(C) 2020 by the authors. Licensee MDPI, Basel, Switzerland. This article is an open access article distributed under the terms and conditions of the Creative Commons Attribution (CC BY) license (http://creativecommons.org/licenses/by/4.0/). 